\section{LOTTE PHILIPSEN}

\section{PÅ ØLEJR MED SAMTIDSKUNSTEN}

CHRISTIAN GETHER, STINE HØHOLT, MARIE LAURBERG (RED.): Utopia \& Contemporary Art Ostfildern, 2012, (ARKEN Museum of Modern Art \& Hatje Cantz Verlag), $176 \mathrm{~s}$.

Umiddelbart er det vanskeligt at afkode, hvilken form for udgivelse der er tale om med antologien Utopia \& Contemporary Art. Indholdsmæssigt består bogen af I4 forskellige bidrag forfattet af et bredt felt af internationale kunsthistorikere, kulturteoretikere og kuratorer, som fra forskellige vinkler analyserer samtidskunstens utopiske aspekter, mens den i sit ydre fremtræder som en lækker, vel-layoutet hardback, spækket med farvegengivelser og tydeligt bærende afsendersignaturerne "Hatje Cantz" og "ARKEN", hvilket sender klare signaler om, at vi her har at gøre med et udstillingskatalog. Forordet oplyser om, at udgangspunktet for bogen er ARKENs Utopia-projekt (2009-20II), der satte fokus på utopi i samtidskunsten, og denne omstændighed forklarer, hvorfor antologiens første tekst - af ARKENs direktør Christian Gether - refererer meget konkret til institutionen ARKEN som et utopisk projekt i sig selv, samtidig med at den mere generelt argumenterer for samtidskunstens fænomenologiske dimension som et særligt utopisk aspekt. Det sidste lykkes ikke helt. Det er således ikke indlysende, at en spontan, kropslig oplevelse af kunst skulle give os indsigt $\mathrm{i}$

"den utopiske stræben, der eksisterer $i$ al god kunst, en utopisk higen efter dybere indsigt i menneskehedens fundamentalt eksistentielle betingelser; en utopisk anstrengelse efter at kunne magte den fornemmelse for menneskehedens mirakel, som har ligget til grund for ny tænkning siden oldtiden og som kommer til udtryk i filosofien såvel som i kunsten” (s. I3).

Desuden virker teksten en kende for højtravende og abstrakt til at kunne fungere som en introduktionstekst til emnet utopi og samtidskunst. Og det er netop et problem med antologien: Man savner simpelthen en velovervejet redaktionel introduktion til, hvad bogen egentlig vil rent indholdsmæssigt. Hvorfor er det overhovedet væsentligt, at vi beskæftiger os med relationen mellem utopi og samtidskunst, og hvad er det for spørgsmål, udfordringer eller tendenser, bogen søger at gøre os klogere på? Det virker, som om bogens status som sidste punktum i ARKENs overordnede utopia-projekt har givet redaktionen den opfattelse, at nærmere begrundelse for udgivelsen er unødvendig. Og det er uheldigt, for at dømme ud fra de enkelte bidrags behandling af emnet, har antologien bestemt selvstændig berettigelse.

I mangel af en egentlig introduktionstekst fungerer Marie Laurbergs tekst "The return of the imaginary" som en overbevisende illustration af utopibegrebets relevans for samtidskunsten. Titlen på Laurbergs tekst spil- 
ler på Hal Fosters Lacan-inspirerede bog Return of the Real fra 1996 og redegør for, hvordan samtidskunsten forbinder sig med det utopiske i sin optagethed af det (kollektivt) imaginære, som - til forskel fra det reelle - er repræsenterbart. Laurberg opstiller en relevant og plausibel analyse af, hvordan store dele af samtidskunsten (fra relationel æstetik til museale totalinstallationer) konkret tilbyder et blik på alternative, utopiske tilværelser.

Flere af antologiens øvrige tekster bidrager med en grundigere indføring $i$ forskellige dimensioner af utopibegrebet, og samlet set opridser antologien dermed variationer over utopibegrebets historiske og teoretiske udfoldelse fra Thomas Mores bog om øen Utopia fra I5I6 over fascismens og socialismens forsøg på at virkeliggøre utopiske samfundsforestillinger i stor skala til I960'er- og I990'er-kunstens afgrænsede, lokale forsøg på at opstille alternative samfund. Bidragenes øvrige forskellighed til trods hersker der blandt forfatterne enighed om, at utopien er kendetegnet ved dels at være en fremtidsforestilling, dels at fremstå som et forbedret alternativ til en eksisterende samfundsorden. Således kvalificerer hverken simple fremskrivninger af status quo eller hedengangne guldaldre sig som utopier.

Antologiens tekster præsenterer (heldigvis) vidt forskellige bud på forholdet mellem samtidskunsten og det utopiske. En interessant diskrepans i synet på dette forhold kommer til udtryk, ved at Jacob Wamberg i sin tekst "No sugar please!" direkte går i clinch med Richard Nobles teori om, at den utopiske del af samtidskunsten adskil- ler sig fra den ikkeutopiske ved at være politisk engageret. Det fungerer fint, at Wambergs tekst er placeret umiddelbart efter Nobles tekst "The politics of utopia”, for mens Noble argumenterer for, at utopisk kunst "formelt adskiller sig fra andre slags kunstneriske reaktioner på den politiske verden (f.eks. aktivisme, dokumentarfilm eller mange forskningsbaserede praksisser), idet den forudsætter et muligt verdensscenarium" (s. 54), argumenterer Wamberg for, at både reklameindustrien, totalitær propaganda og den moderne kunst efter år 1900 generelt fremviser mulige alternative verdensscenarier - med den forskel, at hvor såvel den kommercielle som den totalitære propaganda fremstiller direkte, sukkersøde glansbilleder af fremtiden, er den moderne kunst karakteriseret ved at skabe billeder, hvor vejen fra nutiden til fremtiden er mere kompliceret (s. 6I). Wambergs endelige påstand er således, at det slet ikke er muligt at skelne mellem moderne kunst og utopisk kunst.

Implicit fremstår det tydeligt i bogen, at en rigtig utopi er venstreorienteret. Eksplicit giver Stephen Duncombe i sin tekst "Imagining No-place" en indsigtsfuld redegørelse for utopiens socialistiske karakteristika i Thomas Mores bog, og Malcolm Miles gengiver Herbert Marcuses tanker om, at socialismen skulle fungere som en utopisk negation af det herskende konsumsamfund. Endvidere er det en implicit antagelse hos flere af antologiens forfattere, at årsagen til utopiens socialistiske karaktertræk skal søges i dens vestlige, kapitalistiske kontekst, der har givet anledning til, at avantgar- 
derne (futuristerne undtaget) har haft tradition for at forbinde radikal samfundsforandring og -forbedring med socialistiske og ofte erklærede kommunistiske sympatier. Disse to implicitte antagelser afføder to væsentlige spørgsmål: Hvordan ved man, om et kunstværk udtrykker kritik af kapitalismen? Og hvordan ser det ud med utopisk kunst i socialistiske stater?

Hvis det er et definerende træk ved utopisk kunst, at den skal formulere en kritik af en kapitalistiske samfundsorden, fordrer det, at det er muligt at afgøre, om værket lever op til dette krav. Men da kunstværker ikke er læserbreve, lader det sig i sagens natur ikke nemt afkode, hvad de “mener". Skulle et værk fremstå med et tydeligt politisk budskab, anses det for propagandistisk eller slet og ret plat. Hvor (gode) værker altså ikke direkte artikulerer samfundskritik, kan de godt fremstå enten bekræftende eller kritiske over for en eksisterende billedorden, men eftersom den kapitalistiske reklameindustri i allerhøjeste grad har approprieret aktivistiske modstandsgruppers billedsprog - og omvendt - er det i dag svært at se forskel på "rigtig", venstreorienteret utopikunst, der af kunstneren eller kuratoren er intenderet kapitalkritisk, og "falsk" billedmanipulation sat i værk af markedskræfterne. Antologien leverer selv et eksempel på denne problematik, idet Internationalistisk Ideale i bogen fremviser en af Martha Roslers collager fra Bringing the War Home: House Beautiful, New Series (2008) forestillende mandlige, jakkesætklædte modeller placeret i et eksploderende inferno af en mellemøstlig krigsskueplads - og skriver, at det sker "med det formål at skitsere mulige visioner for samfundet og kunsten i lyset af den globale finanskrise" (s. I05). Her italesættes collagen i et kuratorisk (fører)greb, der søger at fratage billedet dets visuelle tvetydighed - det kunne have været en reklame for Hugo Boss og reducere det til et tegn på den globale finanskrise, hvormed det bliver i stand til at "foregribe og forestille sig det, der endnu ikke findes" (s. I05). At Roslers værk handler om finanskrisen er ikke noget, vi kan se ud af værket, men noget som Internationalistisk Ideale fortæller os.

Med kriteriet om at utopikunst er kapitalismekritisk (hvordan man end efterprøver det i praksis) melder sig spørgsmålet om, hvordan det står til med kunstneriske utopier i socialistiske stater. Antologien imødekommer spørgsmålet ved at indeholde tre artikler om samtidskunst $i$ henholdsvis Cuba, Østeuropa (før og efter Sovjetunionens opløsning) samt Kina. Kendetegnende for de tre artikler er, at de på ganske grundig og nuanceret vis redegør for og analyserer samtidskunsten i disse regioner. I Inke Arns tekst om de to paradigmeskift mellem post-, neo- og retroutopisme i samtidskunsten i Sovjet, Rusland og ex-Jugoslavien bliver analysen imidlertid så lokaldetaljeret, at man trods stor læsevelvilje simpelthen taber tråden og løber sur i de forskellige begrebslige varianter af utopiske tendenser i østblokken. De to øvrige tekster lider lidt under samme tilbøjelighed: De er velskrevne og emmer af viden om deres emner, men fokuserer meget lokalt. Man savner i antolo- 
gien en artikel, som gennem en dybere teoretisk behandling analyserer selve paradokset om samtidskunstens utopiske tendenser i socialistiske samfund.

Slutteligt kan man tilføje, at mens Utopia \& Contemporary Art er spækket med relevante og interessante refleksioner over utopibegrebet og dets relevans for samtidskunsten, er tilsvarende refleksioner over samtidskunstbegrebet totalt fraværende. Det er selvfølge- lig et helt legitimt valg, men det savnes, at redaktionen havde overvejet dette forhold og lanceret det som en præmis i en introduktion - og muligvis var kommet frem til, at det havde været mere retvisende at udskifte den sideordnende titel med det hierarkiske Utopia in Contemporary Art.

Lotte Philipsen er adjunkt ved Institut for Astetik og Kommunikation, Aarhus Universitet. 